\title{
Phytochemical Evidence for the Plant Origin of Brazilian Propolis from São Paulo State
}

Vassya Bankova $^{\mathrm{a}}$, Gergana Boudourova-Krasteva ${ }^{\mathrm{a}}$, Jose M. Sforcin ${ }^{\mathrm{b}}$, Xavier Frete ${ }^{\mathrm{a}}$, Atanas Kujumgiev ${ }^{\mathrm{c}}$, Rita Maimoni-Rodella ${ }^{\mathrm{b}}$ and Simeon Popov ${ }^{\mathrm{a}}$

${ }^{a}$ Institute of Organic Chemistry with Centre of Phytochemistry, Bulgarian Academy of Sciences, 1113 Sofia, Bulgaria

b Instituto de Biociencias, UNESP 18618-000, Botucatu, SP, Brazil

c Institute of Microbiology, Bulgarian Academy of Sciences, 1113 Sofia, Bulgaria

Z. Naturforsch. 54c, 401-405 (1999); received November 16/December 21, 1998

Propolis, Araucaria angustifolia, Baccharis dracunculifolia, Eucalyptus citriodora, Botanical Origin

Propolis and plant secretions from three species, most frequently mentioned as botanical sources of the bee glue in Brazil (Baccharis dracunculifolia, Araucaria angustifolia and Eucalyptus citriodora) have been investigated using GC-MS. Based on chemical evidence, $B$. dracunculifolia was shown to be the main propolis source in São Paulo state. The antibacterial and antifungal activities of all four materials were also tested, the most active being propolis and Baccharis leaf exudate.

\section{Introduction}

Propolis (bee glue) is a sticky dark-coloured material that honeybees collect from living plants, mix it with wax and use in construction and adaptation of their nests. It has been known as a remedy since ancient times and is still used in folk medicine (Ghisalberti, 1979), in "bio-cosmetics", "health foods" and for numerous further purposes (Matsuda, 1994, Wollenweber and Buchmann, 1997). Many studies have shown that in the temperate zones bees almost exclusively collect this material from the bud exudate of poplar trees. This is true for Europe (Tamas et al., 1979; Popravko and Sokolov, 1980; Papay et al., 1986; Greenaway et al., 1987; Bankova and Kuleva, 1989), North America (Garcia-Viguera et al., 1993), the non-tropical regions of Asia (Bankova et al., 1993; Chi et al., 1996) and even New Zealand (Markham et al., 1995); in North Russia however, birch buds (Betula verrucosa) supply bees with the glue. In the last few years, tropical and especially South American propolis has become a subject of increasing interest, for both commercial and scientific reasons (Aga et al., 1994; Tomas-Barberan

Reprint requests to Dr. V. Bankova.

Fax: 0035 92-700-225

E-mail: IOCHNP@BGCICT.ACAD.BG et al., 1993; Matsuda, 1994; Wollenweber and Buchmann, 1997). Since in tropics there are no poplar trees, the origin of tropical propolis is still an open question. Vegetable propolis sources have been reported from tropical countries (Crane, 1988); however, most of the reports are based on bee observations only and not on chemical analyses of propolis.

The best indicator for the origin of propolis is its chemical composition, compared to the composition of the hypothetical source plant material. In this work, we report a comparative chemical investigation of propolis from Brazil, São Paulo State, and some plant secretions (collected in the vicinity of the hives), that have been reported to be potential propolis sources: from Araucaria (Bankova et al., 1996; Miyataka et al., 1997), Baccharis (Bankova et al., 1995; Wollenveber and Buchmann, 1997) and Eucalyptus (Crane, 1988; Miyataka et al., 1997).

\section{Experimental}

\section{Propolis}

Propolis was harvested in the bee keeping Section of the School of Veterinary Medicine and Animal Husbandry of Botucatu, UNESP, in January 1998, from the hives of cultivated honey-bees (Apis mellifera). 


\section{Plant material}

Leaves from Baccharis dracunculifolia DC and Araucaria angustifolia (Bert.) O. Kunt, and trunk from Eucalyptus citriodora Hook were collected at the same location and the same time as the propolis and identified by Dr. R. C. S. Maimoni-Rodella, UNESP.

\section{Extraction}

$35.4 \mathrm{~g}$ propolis was ground and extracted with $360 \mathrm{ml} \mathrm{70 \%} \mathrm{ethanol} \mathrm{at} \mathrm{room} \mathrm{temperature} \mathrm{for} 24 \mathrm{~h}$ (yield of dry extract $12.4 \mathrm{~g}, 53 \%$ ). Fresh plant material was briefly extracted with acetone to dissolve the lipohpilic surface material (exudate). A. angustifolia: $750 \mathrm{~g}$ leaves with $750 \mathrm{ml}$ acetone, $2.54 \mathrm{~g}$ dry extract $(0.3 \%) ;$ B. dracunculifolia: $245 \mathrm{~g}$ with $500 \mathrm{ml}$ acetone, $22.5 \mathrm{~g}$ dry extract $(9.1 \%)$, E. citriodora: $1215 \mathrm{~g}$ with $1500 \mathrm{ml}$ acetone, $39.5 \mathrm{~g}$ dry extract $(3.2 \%)$.

\section{TLC analysis}

TLC was carried out on silica gel Alufolien Kieselgel Merck $\mathrm{F}_{254}$, mobile phases hexane/ethyl acetate $7: 3 \mathrm{v} / \mathrm{v}$; chloroform/ethyl acetate $7: 3 \mathrm{v} / \mathrm{v}$; chloroform $/ \mathrm{methanol} /$ water $60: 22: 4 \mathrm{v} / \mathrm{v} / \mathrm{v}$. The spots were visualized by spraying with $60 \%$ sulfuric acid in ethanol and heating to $120^{\circ}$, or for phenolics by spraying with $20 \%$ ferric chloride in methanol.

\section{GC-MS analysis.}

The GC-MS analyses were performed after silylation of the dry extracts $(2.5 \mathrm{mg}$ extract, $20 \mu \mathrm{l}$ dry pyridine, $30 \mu \mathrm{l} \quad \mathrm{N}, \mathrm{O}$-bis(trimethylsilyl)trifluoroacetamide, $80^{\circ} \mathrm{C}, 20 \mathrm{~min}$ ). A $30 \mathrm{~m} \times 0.25 \mathrm{~mm}$ i. d. SPB-1 fused silica capillary column was used in a HP5890 gas chromatograph with a HP 5972 MSD detector. The linear velocity of the carrier gas (helium) was $38.2 \mathrm{~cm}$. $\mathrm{sec}^{-1}$. The samples were introduced via an all-glass injector working in the split mode, with a temperature program $80-240{ }^{\circ} \mathrm{C}$ at $8 \mathrm{deg} \cdot \mathrm{sec}^{-1}, 240-300{ }^{\circ} \mathrm{C}$ at $121 \mathrm{deg} \cdot \mathrm{sec}^{-1}$. The identification was accomplished using computer search of commercial libraries. In some cases, when identical spectra were not found, only the structural type of the corresponding component was proposed, based on its mass spectrum. Reference compounds were co-chromatographed where possible to confirm GC retention times.

\section{Isolation of compounds from plant exudates}

Using column chromatography (CC) on silica gel with mobile phases chloroform-acetone with increasing polarities, from $B$. dracunculifolia exudates the flavonoids kaempferid (1), aromadendrine-4'-methyl ether (2) and 5,6,7-trihydroxy$3,4^{\prime}$-dimethoxyflavone (3) were isolated and identified by comparison of spectral (UV, ${ }^{1} \mathrm{H}$ NMR, $\left.{ }^{13} \mathrm{C} \mathrm{NMR}\right)$ and chromatographic properties with authentic samples. From $A$. heterophylla exudates, by $\mathrm{CC}$ on silica gel, mobile phase hexane-acetone with increasing polarity, $E / Z$ communic acid (4) was isolated as the main component and identified by comparison of spectral $\left({ }^{1} \mathrm{H}\right.$ NMR, ${ }^{13} \mathrm{C}$ NMR $)$ and chromatographic properties with an authentic sample.

\section{Antibacterial tests}

For the investigation of the antibacterial activity we used a modification of bioauthography developed in our laboratory (Kujumgiev et al., 1993). The test micro-organism was Staphylococcus aureus 209 . The activity was measured as diameter of the inhibitory zones in the soft agar layer stained after a 72 -h incubation at $37^{\circ} \mathrm{C}$ with methylene blue according to Loeffler (Doetsch, 1981). An inhibitory zone of $5 \mathrm{~mm}$ corresponds to a lack of activity ( $5 \mathrm{~mm}$ is the diameter of the spot). Control experiments with solvent (ethanol) showed that the solvent did not have any activity. The inhibitory zones of $0.4 \mathrm{mg}$ of each extract were measured.

\section{Antifungal tests}

The agar cup method was used (Spooner and Sykes, 1972), with Candida albicans 562 as the test strain. The activity was measured as a diameter of the inhibitory zones after $96 \mathrm{~h}$ incubation. The inhibitory zones of $0.5 \mathrm{mg}$ of each extract were measured. An inhibitory zone with a diameter less than $10 \mathrm{~mm}$ corresponds to lack of activity $(10 \mathrm{~mm}$ is the diameter of the agar cup). Control experiments with solvent (ethanol) showed that the solvent did not have any activity.

\section{Results and Discussion}

The preliminary investigations showed the striking similarity between TLC patterns of propolis 
Table I. GC-MS data about composition of propolis and plant exudates.

\begin{tabular}{|c|c|c|c|c|c|}
\hline Compound & $\mathrm{RRT}^{\mathrm{a}}$ & Propolis & $\begin{array}{r}\text { Baccharis } \\
\%\end{array}$ & $\begin{array}{l}\text { Araucaria } \\
\text { of } \text { TIC }^{\text {b }}\end{array}$ & Eucalyptus \\
\hline p-Coumaric acid ${ }^{c}$ & 1.00 & 2.6 & 2.3 & 0.1 & 0.4 \\
\hline Dihydrocinnamic acid ${ }^{\mathrm{d}}$ & 0.58 & 1.9 & 3.6 & - & - \\
\hline Cinnamic acid ${ }^{\mathrm{d}}$ & 0.73 & - & - & - & 1.1 \\
\hline Prenyl-p-coumaric acid ${ }^{\mathrm{e}}$ & 1.24 & 1.6 & 1.2 & - & - \\
\hline Diprenyl-p-coumaric acid ${ }^{c}$ & 1.38 & 18.5 & 37.0 & - & - \\
\hline Aromadendrine $-4^{\prime}$-methyl ether ${ }^{c}$ & 1.46 & 2.8 & 1.5 & - & - \\
\hline Kaempferid $^{c}$ & 1.74 & 1.8 & 1.1 & - & - \\
\hline $3^{\mathrm{c}}$ & 1.76 & 1.0 & 1.0 & - & - \\
\hline$\beta$-Amyrine ${ }^{\mathrm{d}}$ & 1.78 & 2.8 & - & - & - \\
\hline Cycloartenol $^{\mathrm{d}}$ & 1.82 & 6.0 & - & - & - \\
\hline Gallic acid ${ }^{\mathrm{c}}$ & 1.21 & - & - & - & 30.4 \\
\hline$E / Z$ Communic acid ${ }^{\mathrm{c}, \mathrm{f}}$ & $1.22,1.23$ & - & - & 10.2 & - \\
\hline
\end{tabular}

a Relative retention time (to $p$-coumaric acid).

b Total ion current.

c Compounds indentified by comparison with authentic samples.

d Compounds identified by comparison of the mass-spectra with library data.

e Compound indentified on the basis of its mass spectrum.

f Both $E$ - and $Z$-isomers, the \% of TIC concerns both peaks (reference substance was a mixture, see Experimental).

and $B$. dracunculifolia leaf exudate. The GC-MS analyses confirmed this observations (Table I). The main components identified in B. dracunculifolia exudates and in bee glue, according to GCMS, were almost the same: dihydrocinnamic acid, $p$-coumaric acid, prenyl- and diprenyl-p-coumaric acids and flavonoids in similar concentrations. The main flavonoids from $B$. dracunculifolia leaf exudate were then isolated using CC and identified<smiles>[R]c1c(O)cc2oc(-c3ccc(OC)cc3)c(O)c(=O)c2c1O</smiles>

1. $R=R^{\prime}=H$

3. $\mathrm{R}=\mathrm{Me}, \mathrm{R}^{\prime}=\mathrm{OH}$
2<smiles>COc1ccc(C2Oc3cc(O)cc(O)c3C(=O)C2O)cc1</smiles><smiles>C=C[C@H]1C=C[C@H]2C(=C1)CC[C@@H]1[C@@](C)(C(=O)O)CCC[C@@]12C</smiles>

Fig. 1. Kaempferid (1), aromadendrine-4'-methyl ether (2), 5,6,7-trihydroxy-3,4'-dimethoxyflavone (3), $E / Z$ communic acid (4). as kaempferid $\mathbf{1}$, aromadendrine-4'-methyl ether 2 and 5,6,7-trihydroxy-3,4'-dimethoxyflavone $\mathbf{3}$ by comparison of their chromatographic and spectral (UV, ${ }^{1} \mathrm{H}$ NMR, ${ }^{13} \mathrm{C}$ NMR) properties with those of authentic samples, previously isolated from Brazilian propolis in our laboratory (BoudourovaKrasteva et al., 1997). Contrary to the prenylated coumaric acids, these flavonoids have not been found earlier in Baccharis dracunculifolia. This facts present unambiguous evidence that at this location $B$. dracunculifolia leaf exudate is the main propolis source, which is in accordance with our earlier hypothesis (Bankova et al., 1995). Other propolis samples originating from São Paulo, claimed to contain $p$-coumaric acid and its prenylated derivatives (Aga et al., 1994; Marcucci et al., 1998) obviously have the same plant precursor. On the other hand, using GC-MS, in propolis we identified some components which were entirely absent in B. dracunculifolia exudates. These were not only the typical ones for bee glue fatty acids $\left(\mathrm{C}_{16}\right.$, $\mathrm{C}_{18}$ ) and sugars but also some amounts of the triterpenes $\beta$-amyrin and cycloartenol. Surprisingly, according to GC-MS the latter compounds were not present in $A$. angustifolia, neither in E. citriodora (Table I). Their plant origin remains unclear. They are an indication that there is a second plant source, playing a minor role in propolis 
Table II. Antibacterial and antifungal activity of propolis and its potential plant sources.

\begin{tabular}{|c|c|c|}
\hline Material & 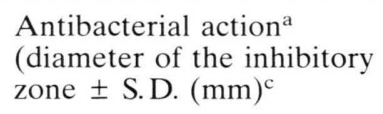 & 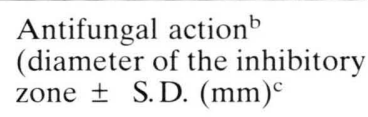 \\
\hline $\begin{array}{l}\text { Propolis } \\
\text { B. dracunculifolia }\end{array}$ & $10.5 \pm 0.5$ & $15 \pm 1$ \\
\hline $\begin{array}{l}\text { leaf exudate } \\
\text { A. angustifolia }\end{array}$ & $9 \pm 1$ & $16 \pm 2$ \\
\hline leaf exudate & $8.2 \pm 0.3$ & 0 \\
\hline E. citriodora resin & $10 \pm 0.5$ & $12 \pm 1$ \\
\hline
\end{tabular}

a Against $S$. aureus.

b Against $C$. albicans.

c Mean of three measurements.

production (the ratio triterpenes/Baccharis components was about 1:7).

Eucalyptus species have been referred to as propolis sources in South America (Miyataka et al., 1997; Bonvehi and Coll, 1994). Our investigation showed that the main components of E. citriodora resin are aromatic acids, a class of compounds that is usually found in bee glue, and sugars. However, the aromatic acid profile of propolis was different from this of E. citriodora. Propolis contained dihydrocinnamic, $p$-coumaric, ferulic and caffeic acids, as well as prenylated derivatives of $p$-coumaric acid, the 3,5-diprenyl derivative being one of the main components of the sample. On the other hand, E. citriodora resin contained cinnamic and $p$-coumaric acid (no prenylated derivatives), and, as a main constituent, gallic acid, which was entirely absent in propolis (Table I). Obviously, bees definitely prefer the compound combination offered by Baccharis leaf exudate!

A. angustifolia exudate contained only traces of aromatic acids, it consisted mainly of terpenes, especially diterpenic acids. The major component of this type was isolated and identified as a mixture of $E$ - and $Z$-communic acid 4, known Araucaria resin components. These compounds, along with other diterpenic acids, were found earlier in propolis from another location in Brazil and for this reason Araucaria species were proposed as possible bee glue source (Bankova et al., 1996). In the propolis from Botucatu, however, no such compounds were identified.

The results obtained, as well as literature data, allow us to point out $B$. dracunculifolia as one of the main sources of propolis in São Paulo State, Brazil. Its typical components, prenylated derivatives of $p$-coumaric acid, have been found in samples from this region investigated earlier, as already mentioned. It is not clear why the bees choose this particular plant source. On the other hand, propolis is thought to be a defence of bees against infections, so it was interesting to compare the antibacterial and antifungal activity of propolis and the plant exudates in order to establish if the bees have made a good choice. We investigated this activity, using as test strains the pathogens Staphylococcus aureus and Candida albicans. The results are presented in Table II.

The antibacterial activity of the four materials is similar, in the antifungal however, there are some differences. Propolis and B. dracunculifolia leaf exudate showed the highest (and practically identical) antifungal action, E. citriodora has lower activity and $A$. angustifolia is not active against the test strain. Obviously, the bees have chosen the best agent to protect their hives against bacterial and fungal infections.

The genus Baccharis is widespread in South America, so it appears meaningful to investigate some other species in order to find out if they are propolis sources, too.

\section{Acknowledgements}

The partial support of this work by the National Foundation for Scientific Research of Bulgaria (Contract \# X-715) is gratefully acknowledged. 
Aga H., Shibuya T., Sugimoto T., Kurimoto M. and Nakajima Sh. (1994), Isolation and identification of antimicrobial compounds in Brazilian propolis. Biosci. Biotech. Biochem. 58, 945-946.

Bankova V., Dyulgerov A., Popov S., Evstatieva L., Kuleva L., Pureb O. and Zamyansan Z. (1993), Propolis produced in Bulgaria and Mongolia: phenolic compounds and plant origin. Apidologie 23, 79-85.

Bankova V., Christov R., Kujumgiev A., Marcucci M. C. and Popov S. (1995), Chemical composition and antibacterial activity of Brazilian propolis. Z. Naturforsch. 50c, $167-172$.

Bankova V., Marcucci M. C., Simova S., Nikolova N. and Popov S. (1996), Antibacterial diterpenic acids from Brazilian propolis. Z. Naturforsch. 52c, 277-280.

Bankova V. and Kuleva L. (1989), Phenolic compounds in propolis from different regions in Bulgaria. Shivotnovadni nauki 2, 94-98 (in Bulgarian).

Bonvehi J. S. and Coll F. V. (1994), Phenolic composition of propolis from China and South America. Z. Naturforsch. 49c, 712-718.

Boudourova-Krasteva G., Bankova V., Sforcin J. M., Nikolova N. and Popov S. (1997). Phenolics from Brazilian propolis. Z. Naturforsch. 52c, 676-679.

Chi J., Chin H. and Xue B. (1996), Isolation and identification of a new cinnamate ester in Laoxi propolis. Yaoxue Xuebao 31, 550-560 (in Chinese) CA126: 115828 p.

Crane E. (1988), Beekeeping: Science, Practice and World Recources. Heinemann, London, pp. 367-372.

Doetsch R. N. (1981), Manual Methods for General Bacteriology, p. 24. American Society of Microbiology Publ. House, Washington D.C.

Ghisalberti, E. (1979) Propolis: a review. Bee World 60, 59-84.

Garcia-Viguera C., Ferreres F. and Tomas-Barberan F. A. (1993), Study of Canadian propolis by GC-MS and HPLC. Z. Naturforsch. 48c, 731-735.

Greenaway W., Scaysbrook T and Whatley F. R. (1987), The analysis of bud exudate of Populus $\times$ euramericana, and of propolis, by gas chromatography-mass spectrometry. Proc. Roy. Soc. Chem. Lond. B 232, $249-272$.
Kujumgiev A., Bankova V., Ignatova A. and Popov S. (1993), Antibacterial activity of propolis, some of its components and their analogs. Pharmazie 48, 785786.

Marcucci M. C., Rodriquez J., Ferreres F., Bankova V., Groto R. and Popov S. (1998), Chemical composition of Brazilian propolis from São Paulo State. Z. Naturforsch. 53c, 117-119.

Markham K. R., Mitchel K. A., Wilkins A. L., Daldy J. A. and Lu Y. (1995), HPLC and GC-MS identification of the major organic constituents in New Zealand propolis. Phytochemistry 42, 205-211.

Matsuda, Sh. (1994), Propolis - health care food. Foods and Food Ingredients Journal of Japan 160, 64-73.

Miyataka H., Nishiki M., Matsumoto H., Fujimoto T., Matsuka M. and Satoh T.(1997), Evaluation of propolis. I. Evaluation of Brazilian and Chinese propolis by enzymatic and physico-chemical methods. Biol. Pharm. Bull. 20, 496-501.

Papay V., Toth L., Soltes M, Nagy E. and Litkei G. (1986), Isolated compounds from Hungarian propolis and populi gemma. Stud. Org. Chem. (Amsterdam) 23, 233-240.

Popravko A. S. and Sokolov I. V. (1980), Plant sources of propolis. Pchelovodstvo (2), 28-29 (in Russian).

Spooner F. D. and Sykes G. (1972), Laboratory assessment of antibacterial activity. In: Methods in Microbiology (Norris J. R. and Ribbons D. W., Eds.), vol. 7B. Academic Press, London and New York, pp. 216-217.

Tamas M., Marinescu I. and Ionescu F. (1979), Flavonoidele din mugurii de plop. Studii si cercetari de biochimie 22, 207-213 (in Rumanian).

Tomas-Barberan F., Garcia-Viguera C., Vit-Olivier P., Ferreres F. and Tomas-Lorente F. (1993), Phytochemical evidence for the botanical origin of tropical propolis from Venezuela. Phytochemistry 34, 191-196.

Wollenweber E. and Buchmann St. (1997), Feral honey bee in the Sonoran Desert: propolis sources other than Poplar (Populus spp.). Z. Naturforsch. 52c, $530-535$. 